\title{
Physical Activity in Adolescent with Mental Retardation: Is Adapted Basketball Training Adequate Stimulus to Improve Cardiorespiratory Fitness and Sport Skills Performance?
}

\author{
Miodrag Kocić1, Ivana Bojić ${ }^{1}$, Marko Aleksandrović1, \\ Aleksandar Ignjatović ${ }^{2}$, Dragan Radovanović ${ }^{1}$ \\ ${ }^{1}$ University of Niš, Faculty of Sport and Physical Education, Niš, Serbia \\ ${ }^{2}$ University of Kragujevac, Faculty of Education in Jagodina, Kragujevac, Serbia
}

\section{SUMMARY}

The purpose of the study was to examine the effects of an adapted basketball training program on the cardiorespiratory fitness and sport skills performance of adolescents with mental retardation (MR). Fifty adolescents with mild MR who participated in this study were divided in two groups. Experimental group $(\mathrm{n}=$ 25 ; mean \pm SD age: $15.7 \pm 0.9$ years) performed the adapted training program, four times per week during eight weeks. A control group $(n=25$; mean \pm SD age: $15.9 \pm 0.8$ years) followed ordinary physical education classes and continued with their normal lifestyle. Exercise testing included the six-minute walk test (6MWT), monitoring of heart rate frequency and sport skills performance test battery.

Results showed a significant difference between groups pre- and post-treatment in 6MWT distance. The experimental group experienced a $10 \%$ increase in covered distance pre- to post-testing $(p<0.05)$, whereas controls had no significant changes in the same period. Conducted adapted training also resulted in significant improvement in examined sport skills performance. However, this kind and duration of experimental procedure did not result in significant differences in anthropometric variables and heart rate frequency. This study demonstrated that adapted basketball training is an adequate stimulus for improvement in cardiorespiratory fitness and sport skills performance of adolescents with mild MR. The advantage of this type of adaptive training program is that it does not require a large financial input, but only the engagement of a qualified and dedicated physical education professor.

Key words: adapted basketball training, mild mental retardation, cardiorespiratory fitness 


\section{INTRODUCTION}

Regular physical activity during adolescence, especially in the case of people with intellectual disability, is of essential importance for the improvement of health, proper growth and development (1-4). The actual guidelines recommend at least 60 minutes of moderate to intense physical activity for adolescents several days a week $(5,6)$. Further, persons with mental retardation (MR) have similar response to exercises compared to peers without disabilities, although there is an increased need for movement (7). However, previous studies have indicated that individuals with intellectual disability score have lower results in standardized tests for physical fitness in all phases of their life, compared to the normal population of the same gender and age ( 3 , 4,8 ). An appropriate level of physical fitness is considered important to the health of people with intellectual disability, and regular physical activity throughout life is recommended for non-communicable disease prevention. Moreover, regular physical activity of people with intellectual disability contributes to their mental and physical progress, increases emotional stability and the motivation to live $(9,10)$.

It can be assumed that a lower level of physical fitness among individuals with mild MR is the consequence of a sedentary lifestyle and the lack of possibility to participate in any form of adapted physical activity, especially in states with low-income or lower-middle economies. Previous investigations indicate that physical activity can improve the quality of life of individuals with MR, and therefore it is recommended to include this population in various programs of adaptive physical activities (9-13). Cardiorespiratory (aerobic) and muscle endurance, as well as muscle strength and balance, can be reduced to such a great extent among individuals with MR that they impede the daily functioning $(14,15)$. These factors can have an additional negative effect on the level of obesity, balance and risk of a fall $(16,17)$. Previous studies confirmed the effects of physical training on physical fitness and well-being in people with mild intellectual disabilities (14). Ozmen at al. (18) have showed positive effect of school-based cardiovascular training on shuttle run performance in children with MR. All previously mentioned reports clearly indicate that physical activity can improve the physical fitness, work capacities and quality of life of individuals with mild MR. Additionally, the results of our previous pilot study $(19,20)$ have enabled the design of a full-scale experiment on this topic. To the best of the authors' knowledge, there has been no study which investigated the effects of an adapted basketball training program on adolescents with mental retardation. Furthermore, no study so far has determined the effect of integrated training participation on cardiorespiratory fitness, body composition and motor skills. Therefore, the purpose of this study was to examine the effects of an adapted basketball training program on the cardiorespiratory fitness and sport skills performance of adolescents with MR. We chose this sport activity because of the nature of the basketball environment and the popularity of this sport in our country, believing that this will be an additional motivation for participants, increasing their compliance and facilitating the implementation of the planned program. It was assumed that the implemented adapted basketball training program would result in improved cardiorespiratory fitness and sport skills performance in adolescents with mild MR.

\section{MATERIAL AND METHODS}

\section{Participants}

Fifty adolescents with mild mental retardation (27 males and 23 females) participated in the study. All of them were classified as having mild mental retardation, lived at home and none of them was institutionalized. They were divided into two groups: experimental (EG, $\mathrm{n}=25$, age $15.7 \pm 0.9$ years) and control (CG, $\mathrm{n}=25$, age $15.9 \pm 0.8$ years). All participants were included into regular school activities with physical education classes, while participants from experimental group performed a specially adapted basketball training program in duration of eight weeks. The adapted basketball training program and regular physical education classes were not held on the same day. All of the participants underwent a physical examination performed by a specialist in sports medicine for athletic eligibility. None of the participants showed any evidence of recent injury in their anamnesis or clinical report.

\section{Ethical clearance}

The Human Investigation Committee of the Faculty of Sport and Physical Education of University of Niš approved the study (No. 04-6/2012), and after that decision the Institutional Board of Special Schools for Elementary and Secondary Education, "14. oktobar" in Niš also approved the study. A written informed consent was obtained from all the participants and from their parents or their legal guardians (if indicated) after a detailed description of the procedures was provi- 
ded. The procedures presented were in accordance with the ethical standards in human research.

\section{Procedures}

Based on the experience in the previous pilot study (20), a specially adapted basketball training program was conducted four times per week, during eight consecutive weeks. Each training session lasted between 25-35 minutes. The first 5 minutes were spent in dynamic warm-up to set the tone for the training session, and the last 5 minutes were spent in some stretching exercise to help relax the body. Within the eight-week training activities, the subjects had 32 training sessions overall. The duration of the training sessions during the first four weeks ranged from 25 to $30 \mathrm{~min}$ and 30 to $35 \mathrm{~min}$ after the fourth week. The overall time of the training activities during the first four weeks ranged from 130 to $150 \mathrm{~min}$ and up to 175 $\mathrm{min}$ in the other four weeks of training. Before performing the specific-motor skills test battery, the participants had a variable number of familiarization sessions, depending on how fast they became accustom med to field tests. They were helpful in teaching participants the correct exercise execution model.

\section{Measures}

Anthropometric measurements included body height, body weight, and percentage of fatty tissue. Body height was measured by means of an anthropometer (GPM, Switzerland), employing a standardized procedure (21). The measurement results were accurate within $0.1 \mathrm{~cm}$. Body weight was measured by means of electronic scales (Tefal, France), with accuracy within $0.1 \mathrm{~kg}$. Body composition measurement was performed using a device for bioelectrical impedance analysis BF 300 (Omron, Japan). The measurement was performed abiding by the manufacturer's instructions. Data regarding the percentage of fatty tissue were read off the display with a $0.1 \%$ accuracy. Resting heart rate, heart rate during and at the end of a six-minute walk test (6 MWT) were determined continuously using automated telemetric monitoring system (Polar, Finland).

For the evaluation of general and integrated responses of all the organ systems involved in physical activity, the 6MWT was used (22). The tests does not offer any concrete information regarding the function of each of the various organs and systems which take part in physical activity, as it is possible with standardized laboratory load tests using suitable equipment for cardio-pulmonary studies. Nevertheless, since most of the daily activities take place up to the level of submaximal intensity, the 6MWT offers a satisfactory insight into the functional state of the bodies of the participants, which is necessary for daily physical activities $(22,23)$, and which has been used in previous research involving individuals with special needs, including those suffering from mental retardation (24).

The six-minute walk test, conducted at the participant's own pace on a flat surface $30 \mathrm{~m}$ in length, in a gym, was carried out according to a standardized protocol while adhering to the existing recommendations $(22,23)$. The participants were assigned the task of crossing as great a distance as possible in a period of 6 min, walking at a tempo which suited them, but without running. The participants received instructions and were continuously motivated during the test. In addition, the participants were allowed to stop at any point during the test, but were encouraged to continue once again in the shortest time possible. The covered distance following the period of $6 \mathrm{~min}$ was measured to the closest meter. With the aim of a more simplified measurement of the covered distance, at intervals of $1 \mathrm{~m}$ along the edge of the surface on which the test was being carried out, alternating markers of a fluorescent green and orange color were placed.

The subjects of this study performed the first ability level of modified basketball tests designed for players with mental retardation, as described in previous studies $(25,26)$, characterized by the analysis of four fundamental areas related to the technical and basic aspects of this game: ball handling, reception, passing, and shooting. Each area was divided into five specific components, in which the athletes obtained an individual score: 1 point for a correct performance; 0.5 points for an incorrect performance; and 0 points for a completely failed attempt. Subject could reach a maximum of 20 points, and were always evaluated by the same team of investigators.

\section{Statistical analyses}

All data are presented as mean $\pm \mathrm{SD}$, and all statistical analyses were performed using the SPSS version 16.0 (SPSS Inc., Chicago, IL) software. Kolmogorov-Smirnov test showed that none of the variables deviated from the normal distribution ( $p>0.05$ ). Changes in physical fit-ness and specific-motor skills were analyzed separately using 2 × 2 (group $x$ time) repeated measure analysis of variance (ANOVA). Statistical significance was set at $p<0.05$. 
Table 1. Participants' anthropometric variables during an 8-week experimental period (Mean \pm SD)

\begin{tabular}{c|c|c|c|c}
\hline \hline \multirow{2}{*}{ Variables } & \multicolumn{2}{|c|}{ Experimental group (n= 25) } & \multicolumn{2}{c}{ Control group (n= 25) } \\
\cline { 2 - 5 } & Initial & Final & Initial & Final \\
\hline Body height $(\mathrm{cm})$ & $156.7 \pm 15.1$ & $157.1 \pm 14.8$ & $158.1 \pm 14.8$ & $158.8 \pm 15.7$ \\
Body weight $(\mathrm{kg})$ & $56.4 \pm 16.4$ & $56.8 \pm 16.1$ & $57.2 \pm 13.5$ & $58.5 \pm 15.9$ \\
Body fat mass (\%) & $20.9 \pm 7.7$ & $20.1 \pm 8.1$ & $21.2 \pm 8.9$ & $21.7 \pm 9.3$ \\
\hline \hline
\end{tabular}

Table 2. Pre- and post- treatment means (SD) of resting heart rate (HR_REST) and heart rate at the end of a six-minute walk test (HR_6MWT) for both groups

\begin{tabular}{c|c|c|c|c}
\hline \hline \multirow{2}{*}{ Variables } & \multicolumn{2}{|c|}{ Experimental group $(\mathbf{n}=\mathbf{2 5})$} & \multicolumn{2}{c}{ Control group $(\mathbf{n}=\mathbf{2 5})$} \\
\cline { 2 - 5 } & Initial & Final & Initial & Final \\
\hline HR_REST & $83.56 \pm 7.74$ & $82.08 \pm 6.59$ & $82.72 \pm 6.22$ & $83.32 \pm 6.07$ \\
HR_6MWT & $121.76 \pm 19.44$ & $115.44 \pm 10.73$ & $119.88 \pm 15.69$ & $117.52 \pm 13.39$ \\
\hline \hline
\end{tabular}

\section{RESULTS}

Conducted for a period of eight weeks, the specially adapted basketball training program did not result in any statistically significant changes in body weight and body fat percentage of the experimental group participants (Table 1). There were no statistically significant changes in the control group either.

The repeated measures ANOVA revealed no statistically significant difference between groups preto post-treatment in resting heart rate $(\mathrm{F}[1.48]=0.19 . \mathrm{p}$ $=0.66)$ and heart rate at the end of six-minute walk test $(\mathrm{F}[1.48]=1.99 . \mathrm{p}=0.16)$.

The repeated measures ANOVA revealed a statistically significant difference between groups preto post-treatment $(\mathrm{F}[1.48]=6.49 . \mathrm{p}<0.05)$ in $6 \mathrm{MWT}$ distance. The experimental group experienced a $10 \%$ increase in covered distance pre- to post-testing ( $\mathrm{p}<$ $0.05)$, whereas controls had no statistically significant changes in the same period (Figure 1).

\section{DISCUSSION}

The main purpose of conducted study was to evaluate the effects of an eight-week adapted basket ball training program on the cardiorespiratory fitness of adolescents with mild mental retardation. The findings of the conducted study clearly show that eight weeks of a adapted basketball training program resulted in a improvement of the ability to cover a longer dista- nce during the $6 \mathrm{MWT}$. On the basis of the significant differences found, we can with certain reliability consider that the structure and length of the adapted basketball training program induced an improvement in the level of cardiorespiratory endurance among the participants with MR. Also, these results indicate that the applied training program involves all limbs through different movement and action. Previous investigation reported that individuals with intellectual disability usually have $8-12 \%$ lower cardiorespiratory capacity (27), and approximately 15 beats/min lower values of maximal heart rate frequency (28), in comparison to the values of the normal population of the same gender and age. Based on our results, it means that even short term training program could increase cardiorespiratory fitness level in adolescent with MR to the level of their peers without disabilities.

On the other hand, intensity of conducted program and/or its duration of eight weeks were not sufficient to induce significant changes in anthropometrical variables and frequency of heart rate (Tables 1 and 2). Nevertheless, the obtained results have shown whether in the case of these variables a difference occurred, and so we can assume that the increase in work intensity or duration of the program could lead to significant changes of body composition with a decrease in body fat. Previous weight survey on adult persons with mental retardation reported inversely proportional relation between intelligence and the percentage of body fat (29). Moreover, approximately $20 \%$ of adults with intellectual disability were classified as obese, and insufficient physical activity accompanying with seden- 
tary lifestyle is considered to be the main reason (30). The second purpose of this study was to assesses the effects of adapted basketball training program on the sport skills performance of adolescents with mild

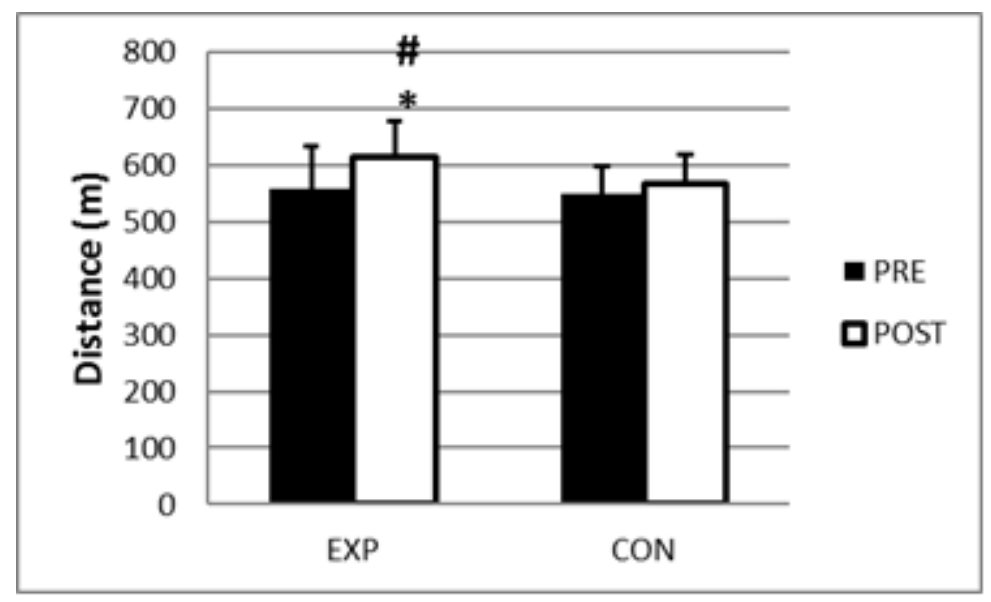

Figure 1. The covered distance (CD) in the experimental (EXP) and control group (CON) pre- and post-training. All of the values are expressed as mean \pm SD. * Significant difference between pre and post measurement $\mathrm{p}<0.05$. \# Significant difference between groups $(\mathrm{p}<0.05)$.

Table 3. Basketball skill parameters before and after an 8-week training intervention (Mean \pm SD)

\begin{tabular}{c|c|c|c|c|c|c}
\hline \hline \multirow{2}{*}{ Variables } & \multicolumn{3}{|c|}{ Experimental group (n= 25) } & \multicolumn{3}{c}{ Control group (n = 25) } \\
\cline { 2 - 7 } & Initial & Final & Change \% & Initial & Final & Change \% \\
\hline Ball Handling & $3.71 \pm 0.67$ & $4.11 \pm 0.39$ & $11 \%$ & $3.82 \pm 0.62$ & $3.86 \pm 0.52$ & $1 \%$ \\
Reception & $4.23 \pm 0.51$ & $4.36 \pm 0.38$ & $3 \%$ & $4.15 \pm 0.42$ & $4.20 \pm 0.36$ & $1 \%$ \\
Passing & $3.99 \pm 0.44$ & $4.28 \pm 0.28$ & $8 \%$ & $4.05 \pm 0.43$ & $4.11 \pm 0.32$ & $1 \%$ \\
Shooting & $3.15 \pm 0.66$ & $3.70 \pm 0.45$ & $17 \%$ & $3.23 \pm 0.63$ & $3.40 \pm 0.64$ & $5 \%$ \\
\hline \hline
\end{tabular}

MR. Eight weeks of this specially adapted training program resulted in significant improvement in sport skills performance. We can only hypothesized that some complex interactions, including changes in intercellular signalization, during the conduction of eight-weeks training influence neurological plasticity and contribute to motor learning. In addition, previous investigations suggested that physical activity during training can lead to an increase in the capillary network due to increased oxygen uptake $(26,31)$. Nevertheless, results of our study clearly indicate that the applied adapted basketball program succeeded in motivating the subjects to take an active part in the training. From our point of view, it is very important to create different programs of physical activities, through adapted physical education classes and inclusive activities, in order to provide opportunities for an active lifestyle for adolescents with MR.
A limitation of the conducted study could be that all participants were classified as having mild mental retardation, and they also had had previous experience with the regular physical education classes. This line of researches could be extended to other subpopulations of these individuals and also for other types of intervention (e.g. football, handball volleyball, etc.).

\section{CONCLUSION}

Adapted physical activity represents a good foundation for the development of physical and cognitive abilities, as well as for the improvement of the quality of life of persons with mental retardation. However, there are a lot of objective problems such as a lack of suitable objects, fields, and the high cost of the organization of such forms of physical activity. This study demonstrated that adapted basketball trai- 
ning is an adequate stimulus for improvement in

of adolescents with mild MR. The duration of adaptive cardiorespiratory fitness and sport skills performance

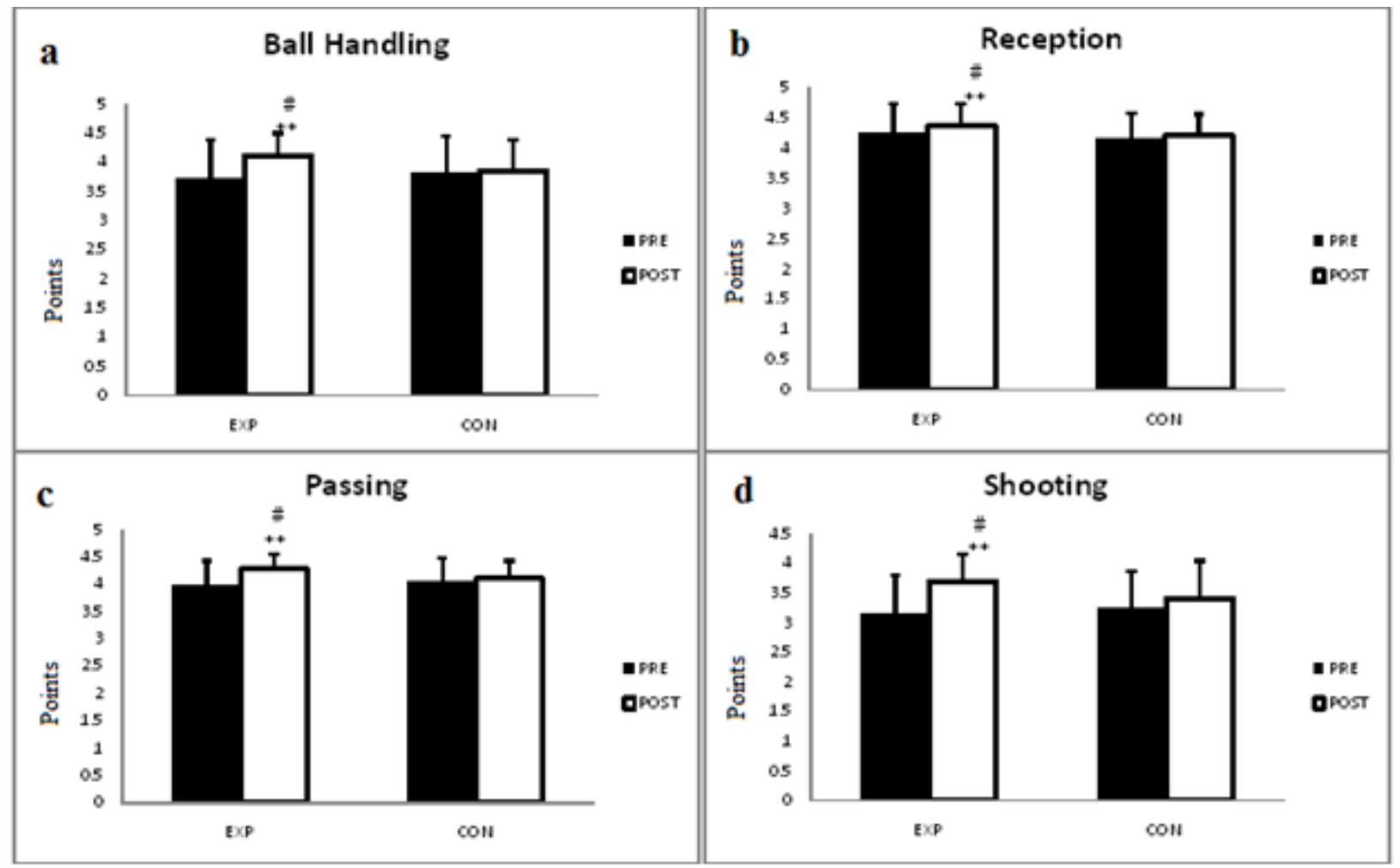

Figure 2. The specific-motor skills test battery for the experimental (EXP) and control group (CON) pre- and post-training in

(a) Ball handling - BH. (b) Reception -R. (c) Passing - P and (d) Shooting - S.

All values are expressed as mean $\pm \mathrm{SD}$.

** Significant difference between pre- and post-measurement $\mathrm{p}<0.01$.

\# Significant difference between groups $(\mathrm{p}<0.01)$.

training program and individual training session fromthis study can be a form of planning activities for adolescents with MR, and tests used can be taken as a measure to evaluate the achieved results. The advantage of this type of adaptive physical activity is that it does not require a large financial input, but only the engagement of a qualified and dedicated physical education professor. 


\section{References}

1. Carmeli E, Barchad S, Lenger R, Coleman R. Muscle power, locomotor performance and flexibility in aging mentally-retarded adults with and without Down's syndrome. J Musculoskelet Neuronal Interact 2002;2(5):457-62.

http://europepmc.org/abstract/med/15758414

2. Cowley PM, Ploutz-Snyder LL, Baynard T, at al. Physical fitness predicts functional tasks in individuals with Down syndrome. Med Sci Sports Exerc 2010;42(2):388-93.

\section{http://europepmc.org/abstract/med/19927019}

3. Chanias AK, Reid G, Hoover ML. Exercise effects on health related physical fitness of individuals with an intellectual disability: A meta-analysis. Adapt PhysActiv Q1998;15(2):119-40. http://journals.humankinetics.com/doi/abs/10.112 3/apaq.15.2.119

4. Graham A, Reid, G. Physical Fitness of adults with an intellectual disability: A 13-year follow-up study. Res Q Exerc Sport2000;71(2):152-61 https://eric.ed.gov/?id=EJ612252

5. Strong W, Malina RM, Blimkie CJR. Evidence based physical activity for school-age youth. JPediatric 2005;146(6):732-37.

http://pubmed.cn/15973308

6. Pitetti K, Beets M, Combs C. Physical activity levels of children with intellectual disabilities during school. Med Sci Sports Exerc2009; 41(8): 1580-86. https://www.ncbi.nlm.nih.gov/pubmed/19568202

7. Kozub FM.Explaining physical activity in individuals with mental retardation: An exploratory study. Educ Train DevDisabil2003;38(3):302-13. http://www.jstor.org/stable/23879829
8. King M, Shields N, Imms C, Black M, Ardern C. Participation of children with intellectual disability compared with typically developing children. Res DevDisabil2013;34(5):1854-62. https://www.ncbi.nlm.nih.gov/pubmed/23528443

9. Rimmer JH, Heller T, WangE, Valerio I. Improvements in physical fitness in adults with Down syndrome. Am JMentRetard2004;109(2):165-74. https://www.ncbi.nlm.nih.gov/pubmed/15000673

10. Howie EK, Barnes TL, McDermott S, et al. Availability of physical activity resources in the environment for adults with intellectual disabilities. Disabil Health J 2012;5(1):41-48.

http://www.sciencedirect.com/science/article/pii/S $\underline{193665741100094 X}$

11. Lloyd M, Temple VA, FoleyJT. International BMI comparison of children and youth with intellectual disabilities participating in Special Olympics.Res Dev Disabil 2012;33(6):1708-14. http://www.sciencedirect.com/science/article/pii/S $\underline{0891422212001060}$

12. Schreuer N, Sachs D, RosenblumS. Participation in leisure activities: Differences between children with and without physical disabilities. ResDev Dis2014;35(1):223-33.

http://www.sciencedirect.com/science/article/pii/S $\underline{0891422213004381}$

13. Pan CY, Liu CW, Chung IC, Hsu PJ. Physical activity levels of adolescents with and without intellectual disabilities during physical education and recess. Res Dev Dis2015;36:579-86. http://www.sciencedirect.com/science/article/pii/S $\underline{0891422214004569}$ 
14. Carmeli E, Zinger-Vaknin T, Morad M, Merrick J. Can physical training have an effect on well-being in adults with mild intellectual disability? Mech Ageing Dev2005;126(2):299-304. http://www.sciencedirect.com/science/article/pii/S $\underline{0047637404002039}$

15. Lahtinen U, Rintala P,Malin A. Physical performance of individuals with intellectual disability: A 30 year follow up. Adapt PhysActiv Q2007; 24(2): $125-43$.

http://journals.humankinetics.com/doi/abs/10.112 3/apaq.24.2.125

16. Hale L, Bray A, Littmann A. Assessing the balance capabilities of people with profound intellectual disabilities who have experienced a fall. J Intellect Disabil Res2007;51(4):260-68.

http://onlinelibrary.wiley.com/doi/10.1111/j.13652788.2006.00873.x/full

17. Beadle-Brown J, Murphy G, Wing L, et al. Changes in skills for people with intellectual disability: A follow-up of the Camberwell Cohort. J Intellect Disabil Res2000;44(1):12-24.

http://europepmc.org/abstract/med/10711646

18. Ozmen T, Ryildirim N, Yuktasir B, Beets MW. Effects of school-based cardiovascular-fitness training in children with mental retardation. Pediatr ExercSci2007;19(2):171-78.

http://journals.humankinetics.com/doi/abs/10.112 3/pes.19.2.171

19. Stanisic Z, Beric D, Bojic I, Nurkic M, Kocic M. The effects of specially adapted basketball training program in adolescents with mental retardation: a pilot study. Serb JSports Sci2012;6(3):89-93.

https://www.cabdirect.org/cabdirect/abstract/2012 $\underline{3331689}$

20. Stanisic Z, Kocic M, Aleksandrovic M, et al. The effects of an adapted basketball training program on the physical fitness of adolescents with mental retardation: a pilot study. Serb JexpClin Res2012;
13(3):103-7.

http://scindeks.ceon.rs/Article.aspx?artid=1820$\underline{86651203103 S}$

21. Eston R, Reilly T. Kinanthropometry and exercise physiology laboratory manual: Tests, procedures and data. Volume 2: Exercise physiology, New York 2002: Routhledge.

22. American Thoracic Society. ATS statement: Guidelines for the six-minute walk test. Am J RespirCrit Care Med2002; 166 (1): 111-17. http://dx.doi.org/10.1164/ajrccm.166.1.at1102

23. Enright PL. The six-minute walk test. Respir Care 2002; 48 (8): 783-85.

http://rc.rcjournal.com/content/48/8/783

24. Elmahgoub SM, Lambers S, Stegen S, et al. The influence of combined exercise training on indices of obesity, physical fitness and lipid profile in overweight and obese adolescents with mental retardation. EurJ Pediatrics2009; 168 (11): 1327-33. http://link.springer.com/article/10.1007/s00431009-0930-3

25. Guidetti L, Franciosi E, Emerenziani GP, et al. Assessing basketball ability in players with mental retardation. Br J Sports Med2009; 43 (3): 208-12. http://bjsm.bmj.com/content/43/3/208

26. Baldari C, Franciosi E, Gallota MC, et al. Using basketball test battery to monitor players with mental retardation across two sports seasons. J Strength Cond Res2009;23(8):2345-50. http://europepmc.org/abstract/med/19826289

27. Fernhall BO, Pitetti KH, Rimmer JH, at al. Cardio respiratory capacity of individuals with mental retardation including Down syndrome. Med Sci Sports Exerc1996; 28 (3): 366-71.

http://europepmc.org/abstract/med/8776225

28. Fernhall B, McCubbin JA, Pitetti KH, et al. Prediction of maximal heart rate in individuals with 
mental retardation. Med Sci Sports Exerc 2001; 33(10):1655-60.

https://www.ncbi.nlm.nih.gov/pubmed/11581548

29. Hove O. Weight survey on adult persons with mental retardation living in the community. Res DevDisabil2004; 25 (1): 9-17.

http://www.sciencedirect.com/science/article/pii/S $\underline{0891422203000908}$

30. Draheim CC, Williams DP, Mccubbin JA. Physical activity, dietary intake, and the insulin resistance syndrome in nondiabeticadults with mental retardation. Am JMentRetard2002; 107(5): 361-75. http://europepmc.org/abstract/med/12186577

31. Dong WK, Greenough WT. Plasticity of nonneuronal brain tissue: roles in developmental disorders. Ment Retard DevDisabil Res Rev 2004; 10 (2): 85-90.

http://onlinelibrary.wiley.com/doi/10.1002/mrdd.2 $\underline{0016 / \mathrm{ful}}$ 


\title{
Fizička aktivnost adolescenata sa mentalnom retardacijom: da li je prilagođeni košarkaški trening program adekvatan podsticaj za unapređenje kardiorespiratornog fitnesa i sport-specifičnih sposobnosti?
}

\author{
Miodrag Kocić1, Ivana Bojić1, Marko Aleksandrović1, \\ Aleksandar Ignjatović ${ }^{2}$ Dragan Radovanović ${ }^{1}$ \\ ${ }^{1}$ Univerzitet u Niš, Fakultet za sport i fizičku kulturu, Niš, Srbija \\ ${ }^{2}$ Univerzitet u Kragujevcu, Fakultet pedagoških nauka u Jagodini, Kragujevac, Srbija
}

\section{SAŽETAK}

Istraživanje je sprovedeno s ciljem da se ispita uticaj prilagođenog programa košarkaškog treninga na kardiorespiratorni fitnes $\mathrm{i}$ sport-specifične sposobnosti kod adolescenata sa mentalnom retardacijom (MR). Istraživanje je obuhvatilo pedeset adolescenata sa blagom $M R$, raspoređenih $u$ dve grupe. Ispitanici eksperimentalne grupe ( $n=25$; srednja vrednost \pm SD uzrasta: $15,7 \pm 0,9$ godina) bili su uključeni u prilagođeni košarkaški trening program, četiri puta nedeljno tokom osam nedelja. Ispitanici kontrolne grupe ( $n=25$; srednja vrednost \pm SD uzrasta: $15,9 \pm 0,8$ godina) bili su uključeni samo u uobičajene časove fizičkog vaspitanja, bez promene životnog stila. Bateriju testova činili su: šestominutni test hodanja (6MTH), praćenje frekvencije srčanog rada i testovi sport-specifičnih sposobnosti.

Rezultati su pokazali značajne razlike između grupa u pređenoj udaljenosti nakon završetka šestominutnog testa hodanja. Ispitanici eksperimentalne grupe pokazali su povećanje od $10 \%$ nakon završenog programa, dok kod ispitanika kontrolne grupe nisu utvrđene značajne promene. Takođe, sprovedeni prilagođen trening doveo je do značajnog poboljšanja sport-specifičnih sposobnosti. Međutim, ova vrsta i trajanje eksperimentalnog programa nisu doveli do značajnih razlika $u$ antropometrijskim varijablama i frekvenciji srca. Sprovedeno istraživanje je pokazalo da je prilagođeni program košarkaškog treninga adekvatan podsticaj za unapređenje kardiorespiratornog fitnesa $i$ sport-specifičnih sposobnosti kod adolescenata sa blagom MR. Prednost ove vrste prilagođenog treninga je što program ne zahteva velika finansijska sredstva, već samo angažovanje kvalifikovanog i motivisanog profesora fizičkog vaspitanja.

Ključne reči: prilagođeni košarki trening, blaga mentalna retardacija, kardiorespiratorni fitnes 